\title{
Risk assessment, risk management and risk-based monitoring following a reported accidental release of poliovirus in Belgium, September to November 2014
}

E Duizer ${ }^{1}$, S Rutjes ${ }^{1}$, AMdR Husman ${ }^{12}$, J Schijven ${ }^{34}$

1. National Institute for Public Health and the Environment (RIVM), Center for Infectious Diseases Control (CIb), Bilthoven, the Netherlands

2. Utrecht University, Institute for Risk Assessment Sciences (IRAS), Utrecht, the Netherlands

3. National Institute for Public Health and the Environment (RIVM), Expert Centre for Methodology and Information Services (SIM), Bilthoven, the Netherlands

4. Utrecht University, Geosciences, Utrecht, the Netherlands

Correspondence: Erwin Duizer (Erwin.Duizer@rivm.nl)

Citation style for this article:

Duizer E, Rutjes S, Husman A, Schijven J. Risk assessment, risk management and risk-based monitoring following a reported accidental release of poliovirus in Belgium, September to November 2014. Euro Surveill. 2016;21(11):pii=30169. DOI: http://dx.doi.org/10.2807/1560-7917.ES.2016.21.11.30169

Article submitted on 11 September 2015 / accepted on 07 January 2016 / published on 17 March 2016

On 6 September 2014, the accidental release of $10^{13}$ infectious wild poliovirus type $3\left(W^{2} V_{3}\right)$ particles by a vaccine production plant in Belgium was reported. $W V_{3}$ was released into the sewage system and discharged directly to a wastewater treatment plant (WWTP) and subsequently into rivers that flowed to the Western Scheldt and the North Sea. No poliovirus was detected in samples from the WWTP, surface waters, mussels or sewage from the Netherlands. Quantitative microbial risk assessment (QMRA) showed that the infection risks resulting from swimming in Belgium waters were above $50 \%$ for several days and that the infection risk by consuming shellfish harvested in the eastern part of the Western Scheldt warranted a shellfish cooking advice. We conclude that the reported release of $\mathrm{WPV}_{3}$ has neither resulted in detectable levels of poliovirus in any of the samples nor in poliovirus circulation in the Netherlands. This QMRA showed that relevant data on water flows were not readily available and that prior assumptions on dilution factors were overestimated. A QMRA should have been performed by all vaccine production facilities before starting up large-scale culture of WPV to be able to implement effective interventions when an accident happens.

\section{Introduction}

On 6 September 2014, the Belgium authorities reported to the European Commission, the World Health Organization (WHO), the European Centre for Disease Prevention and Control (ECDC) and the Dutch focal point for the International Health Regulations IHR the accidental release of $45 \mathrm{~L}$ of concentrated live poliovirus solution on 2 September at Rixensart, Belgium by a vaccine producing company [1]. The concentrated suspension was estimated to contain $10^{13}$ infectious wild poliovirus type $3\left(\mathrm{WPV}_{3}\right)$ particles (Saukett strain) for production of inactivated polio vaccine (IPV). The suspension was released into the sewage system, discharged directly to a wastewater treatment plant (WWTP) in Rosières and subsequently, following treatment, into the river Lasne. The river Lasne is an affluent of the river Dyle which is an affluent of the Schelde river which flows into the Western Scheldt (the Netherlands) and subsequently into the North Sea.

On 6 September, Belgium's High Council of Public Health stated that the risk of infection for the population exposed to the contaminated water was extremely low due to the high level of dilution and the high polio vaccination coverage (95\%) in Belgium. Nevertheless, as a precautionary measure, Belgium's High Council of Public Health advised to avoid water activities in the Lasne downstream of the WWTP and a booster dose of IPV was offered to persons who had been in contact with the water of river Lasne from 2 September until the date when the precautionary measures were to be lifted. The vaccination coverage in some Dutch orthodox-reformed communities along the Western Scheldt is less than $90 \%$. In addition, the IPV offered in Belgium (since 2001) and the Netherlands (since 1957) protects against disease but not against infection. Therefore, it does not efficiently interrupt (faecal-oral) transmission as was shown in Israel: Israel implemented IPV exclusively in 2005 and introduction of WPV type 1 in 2013 resulted in silent transmission that continued for almost a year [2]. Consequently, silent transmission of $W_{3} V_{3}$ after introduction in the Belgium or Dutch population cannot be excluded, while only unvaccinated persons are at risk for disease.

Polioviruses are non-enveloped picornaviruses and stay infectious for several weeks in freshwater and 
Timeline showing sampling dates and the risk assessment and risk management process performed in the Netherlands following an accidental release of poliovirus in Belgium, September-November 2014

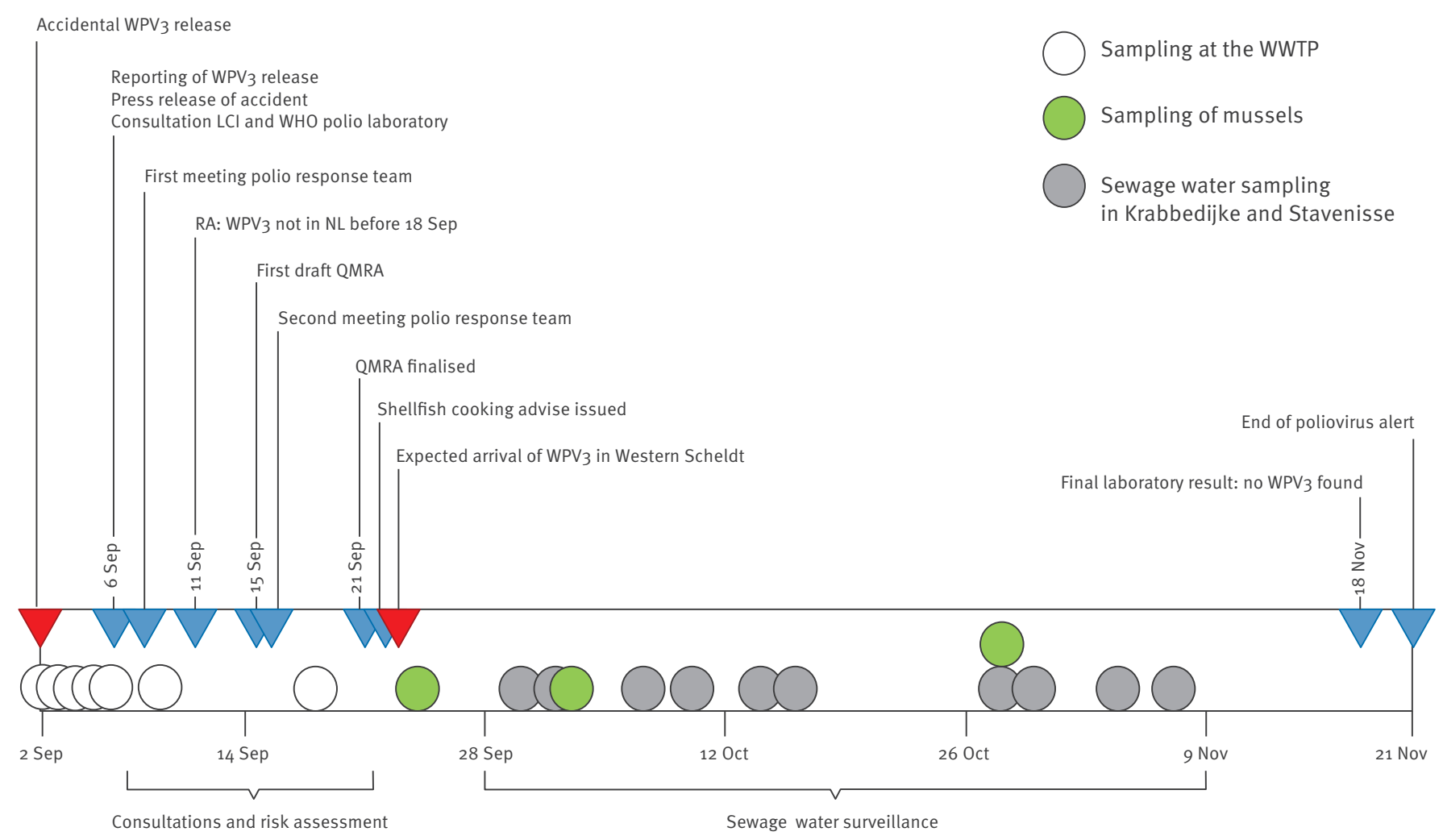

LCI: National Coordination Centre for Communicable Disease Control, the Netherlands; RA: risk assessment; QMRA: quantitative microbial risk assessment; WHO: World Health Organization; WPV3: wild poliovirus type 3; WWTP: wastewater treatment plant.

slightly shorter in seawater [3]. Accidental release may introduce $\mathrm{WPV}_{3}$ into the human population via different routes. Contaminated water may be ingested during swimming. Filter-feeding shellfish, which can concentrate virus particles in their digestive tissue $[4,5]$, may be consumed raw and the shellfish harvesting season was about to start in the Netherlands, in the first week of October 2014.

Because of the risks of circulating wild-type polioviruses and coinciding risks of acute flaccid paralysis (AFP) patients, accidental release of live poliovirus by a vaccine producer may have consequences for the worldwide polio eradication [6]. The European region was certified polio-free in 2002 and has successfully maintained its polio-free status despite numerous challenges. Recently, Ketsuriani et al. concluded that "National polio outbreak preparedness plans need strengthening" within the European region [7]. The authors referred mostly to plans to be executed when an AFP case or poliovirus circulation is already confirmed. In addition, "strategies must be designed to guard against the risk of polio reemergence due to long-term vaccine-derived polio viruses (VDPV) excretors, bioterrorism and accidental release of wild or live vaccine viruses" [6].
This paper describes the actions that were undertaken in the Netherlands following the reporting of the accidental release of $\mathrm{WVP}_{3}$ in Belgium. Based on the infection risks that were assessed by quantitative microbial risk assessment (QMRA), measures were implemented to prevent introduction of $\mathrm{WPV}_{3}$ in the Dutch population and risk-based monitoring was implemented for early detection of poliovirus circulation. Moreover, the paper focuses on the critical control points where the risk assessment and response process can be improved.

\section{Methods}

Consultations and qualitative risk assessment On 8 September, a Dutch response team was convened consisting of representatives of the National Coordination Centre for Communicable Disease Control, the Centre for Zoonosis and Environmental Microbiology (WHO Collaborating Center for Risk Assessment of Food and Waterborne Pathogens) and the Centre for Infectious Diseases Research, Diagnostics and Screening (WHO Specialised Laboratory for Polio) from the RIVM, as well as the Dutch Food Safety Authority (NVWA), the Department of Waterways and Public Works and the Crisis Expert Team Environment and 


\section{FIGURE 2}

Estimated inactivation of wild poliovirus type 3 at $18.5^{\circ} \mathrm{C}$ in water

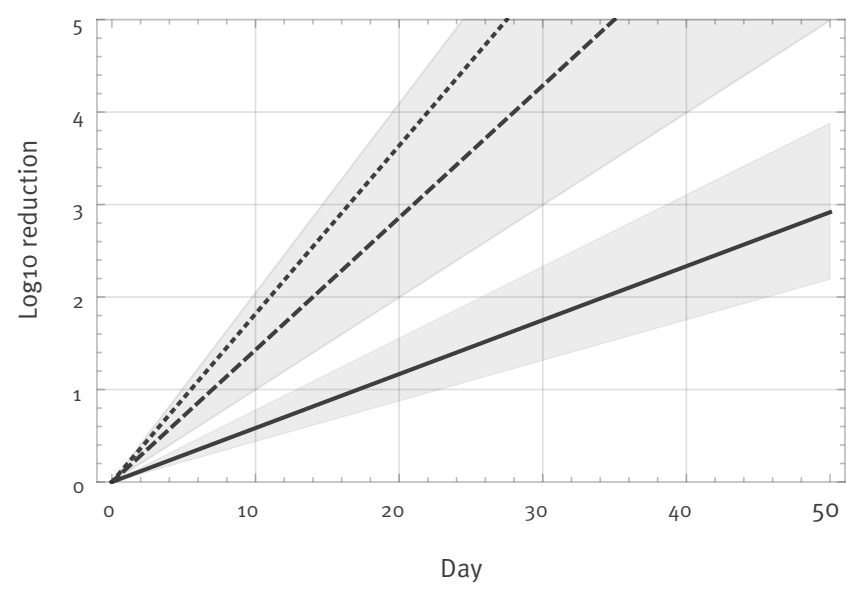

Solid line: freshwater $\left(\mu=0.13\right.$ day $\left.^{-1}\right)$; dashed line: seawater $\left(\mu=0.30\right.$ day $\left.^{-1}\right)$; dotted line: estimated inactivation of wild poliovirus type 3 according to the World Health Organization $\left(\mu=0.42\right.$ day $\left.^{-1}\right)$; grey shading: $95 \%$ confidence intervals.

\section{FIGURE 3}

Probability of exposure and dose-response curves for poliovirus type 1 strain SM for adults and wild poliovirus type 3 strain Fox for premature and newborn infants
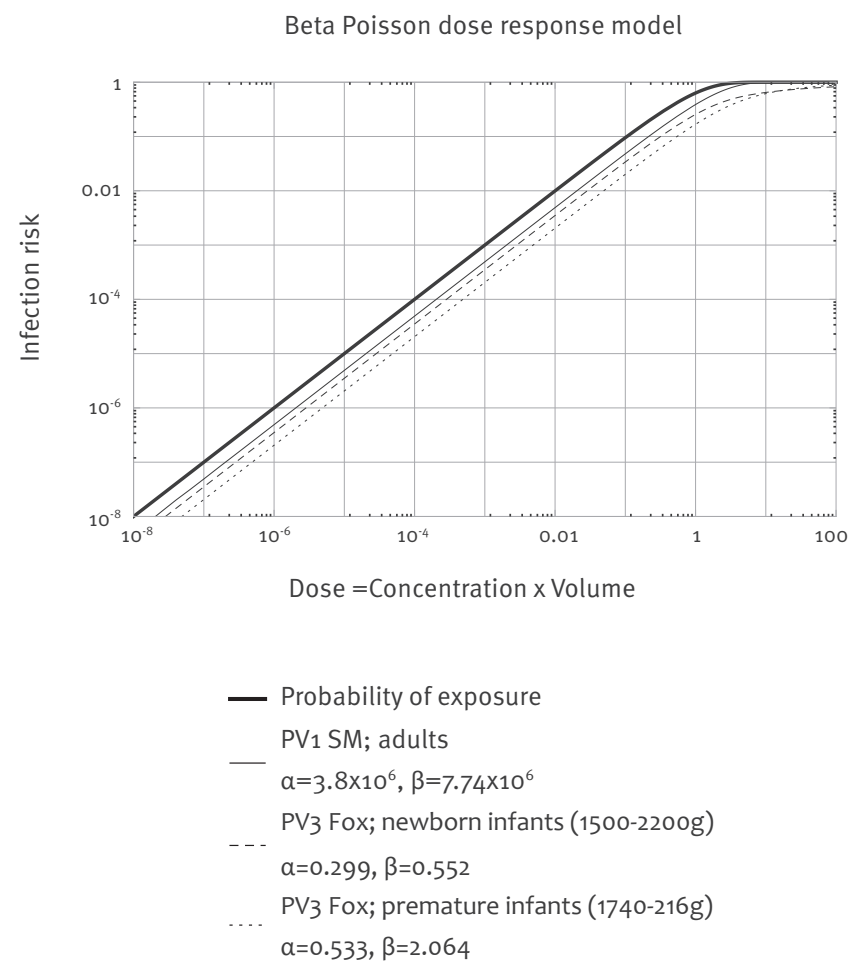

Source: [14].
Drinking Water. In this meeting, the consequences for the Dutch population based on a qualitative risk assessment were discussed as well as possible measures. It was decided to perform a QMRA to support the decision making on public health measures. Between 8 and 21 September 2014 the response team communicated frequently via email, in meetings and teleconferences. Several experts outside the response team were consulted. Throughout the analysis period from 8 September to 18 November, the WHO Regional Office for Europe (WHO/Europe) and the Belgian Scientific Institute of Public Health were updated ad hoc on the laboratory results and progress in the risk assessment (Figure 1). Following a thorough risk assessment by a multidisciplinary group of experts in the response team, two possible routes of transmission that may pose a public health risk were identified: ingestion of contaminated seafood and ingestion of contaminated water during recreational activities. These two routes of transmission were further considered in the next step, the quantitative microbial risk assessment.

\section{Quantitative microbial risk assessment}

WPV 3 concentration in wastewater effluent

The travel time of the wastewater from the pharmaceutical company to the wastewater treatment plant is three to four hours through a ca $3 \mathrm{~km}$ closed sewerage system. We assumed no longitudinal mixing had occurred and the virus load entered the WWTP in a short time interval.

WPV $_{3}$ concentrations in wastewater were estimated using data provided by GlaxoSmithKline (GSK) (10 13 WPV 3 particles in $45 \mathrm{~L}$ ) and data provided by the WWTP. Following primary treatment where particles larger than $6 \mathrm{~mm}$ are removed, treatment continues biologically in two different lines. The first biological line consists of extended aeration with biological nitrification/denitrification and simultaneous physicochemical precipitation of phosphates, in a dual-zone reactor with selector valve and post-anoxia and internal recirculation of nitrates. The second line is similar to the first line but extended with an ultrafiltration system. Under dry weather conditions, the residence time in the WWTP is 22 hours with a discharge rate of $5.3 \times 10^{5} \mathrm{~L} / \mathrm{h}$; assuming full mixing, the dilution factor is $2.6 \times 10^{5}$. Because of mostly conventional wastewater treatment, WPV 3 concentrations were assumed to be reduced by $0.7-2$ $\log _{10}$ (5 to 100 times) [8]. The worst case value of only $0.7 \log _{10}$ reduction was applied in this QMRA.

WPV 3 concentration in the surface waters

The poliovirus particles were assumed to be completely mixed in each water body they passed and subject to inactivation and dilution. Sedimentation (and resuspension) was not considered. Among enteric viruses, poliovirus is relatively stable. First order rate inactivation was calculated using data from a meta-analysis by Bertrand et al. [3] for a temperature of $18.5^{\circ} \mathrm{C}$ : 
$C_{t}=C_{o} \exp (-\mu t)(1)$

where $C_{o}$ is the initial concentration (particles/L), $\mu$ is the inactivation rate coefficient $\left(\mathrm{day}^{-1}\right)$ and $t$ is the time (days). For poliovirus at $18.5^{\circ} \mathrm{C}, \mu=0.13$ in freshwater and $\mu=0.33$ in seawater.

Figure 2 shows reduction by inactivation of poliovirus for freshwater as well as seawater, including model and prediction uncertainty. For comparison, we included the inactivation rate of WPV 3 according to Dowdle and Birmingham as used by WHO [9], showing that inactivation according to $\mathrm{WHO}$ data is within the prediction interval given by Bertrand et al. [3]. The prediction uncertainty is huge, ranging from ca $0.1 \log _{10}$ in 50 days to ca $5 \log _{10}$ in eight days. For the QMRA, we applied the mean inactivation rate according to Bertrand et al. [3].

Travel times in the various water bodies as well as dilution factors representing dry weather conditions, were obtained from Rijkswaterstaat (RWS, Department of Waterways and Public Works, the Netherlands).

Exposure and infection risk from swimming in the Western Scheldt and oyster consumption Because no health-based targets are set for polioviruses in surface water or shellfish, the infection risk that is included in the Dutch drinking water directive for tapwater was taken as a reference for an acceptable risk level [10]. The acceptable infection risk in that directive is set at less than one infection in 10,000 persons that consume unboiled drinking water per year. In this study we set the acceptable risk of infection level at $<1 \times 10^{-4}$ per swimming episode or portion of shellfish consumed raw.

Exposure to $\mathrm{WPV}_{3}$ by swimming in the Western Scheldt during WPV 3 contamination was defined as the ingested number of virus particles of dose $D$. $D$ was calculated from the WPV 3 concentration and the gamma-distributed volume of water $(\mathrm{mL})$ that was swallowed per swimmer per swimming event [11]. The gamma distribution parameter values are $r=0.45$ and $\lambda=60$ (mean: $27 \mathrm{~mL}$ ) for men, $r=0.51$ and $\lambda=35$ (mean: $18 \mathrm{~mL}$ ) for women and $r=0.64$ and $\lambda=58$ (mean: $37 \mathrm{~mL}$ ) for children [12]. In the exposure and risk calculations, 10,000 Monte Carlo samples were generated. Exposure to WPV $_{3}$ by consuming raw shellfish included the consumed amount of raw shellfish per meal and the assumption that shellfish had concentrated WPV 100 or 1,000 times by filtering the water [13]. To estimate the infection risk, the beta-Poisson dose response model for WPV 3 (strain Fox) in newborns was used [14]:

$P_{\text {inf,person, day }}=1-F_{1}(a, a+\beta ;-D)(2)$

where $a$ and $\beta$ are infectivity parameters that are pathogen-specific and $F_{1}$ is the confluent hypergeometric function (Figure 3).
Samples and sampling sites

Samples were collected by GSK or staff from the Catholic University of Leuven and sent to the National Institute for Public Health and the Environment in the Netherlands (RIVM) for analysis after storage at $2-6{ }^{\circ} \mathrm{C}$ for variable times (one night to six weeks). RIVM houses the closest WHO Specialised Laboratory for polio. Sample shipment was facilitated by Belgium's Scientific Institute of Public Health (WIV-ISP) and WHO/Europe. The following samples were analysed: water from the sewage system at GSK, and influent, effluent, sludge and sediment from the WWTP in Rosières. Sludge was removed daily from the WWTP and mixed with high lime doses (40\%). Treated sludge was subsequently incinerated. During the first days after the incident (2-5 September), only water samples were collected, sludge samples from the first days were not available. Mussels were collected in the Western Scheldt east of Kruiningen (Kloosterzande) on 24 September and on 3 and 28 October. Between 30 September and 10 November, 19 sewage samples (1 L grab samples) were collected in the villages of Krabbendijke (sampling a secondary school with ca 500 students aged 11-19 years and staff) and Stavenisse (sampling ca 1,800 individuals of all ages). The vaccination coverage for poliovirus in both communities is less than $80 \%$ [15].

\section{Sample processing}

The water samples were concentrated 50 to 300 times to a volume of $2-3 \mathrm{~mL}$ by ultrafiltration using Amicon ultrafiltration membranes PM10 in Amicon stirred ultrafiltration cells at $50-75$ psi pressure, at $4^{\circ} \mathrm{C}$. When the target volume of $2-3 \mathrm{~mL}$ was reached, the pressure was released and the membrane was rinsed to resuspend the viruses. The concentrated fraction was collected and stored until processing at $-20^{\circ} \mathrm{C}$. Approximately $20 \mathrm{~g}$ sediment and sludge samples were treated as described [16]. Mussel samples were processed on the day of collection and viruses were extracted from $3 \times 10$ batches of five pooled digestive tracts [17].

\section{Virus culture for detection of infectious polioviruses}

The concentrated and pretreated samples were extracted with chloroform $(30 \% \mathrm{v} / \mathrm{v}$, to remove bacteria, fungi and enveloped viruses) and subsequently inoculated $(3 \times 100 \mu \mathrm{L})$ on $3-7$ day-old L2ob cells in tubes for detection of infectious polioviruses. L2ob is a mouse cell line expressing the gene for the human cellular receptor for poliovirus. These cells support isolation of polioviruses 1, 2 and 3 and only a limited number of other human viruses [18]. The inoculated L2ob cells were incubated at $37^{\circ} \mathrm{C}$. The majority of water and sludge samples and the sewage samples from Krabbendijke and Stavennisse were also inoculated on $\mathrm{Rd}$ and Ht-29 cells $(3 \times 100 \mu \mathrm{L}$ for each cell type). These cell lines support isolation of a wide range of human enteric viruses including most enteroviruses $[19,20]$. The inoculated RD and $\mathrm{Ht}-29$ cells were incubated at $37^{\circ} \mathrm{C}$ and $3 \mathrm{rpm}$. Cytopathic effect (CPE) was monitored 
Part of Belgium and the Netherlands showing the estimated concentrations of wild poliovirus type 3 in water bodies and the DKTP vaccination rates in the Netherlands, September-November 2014

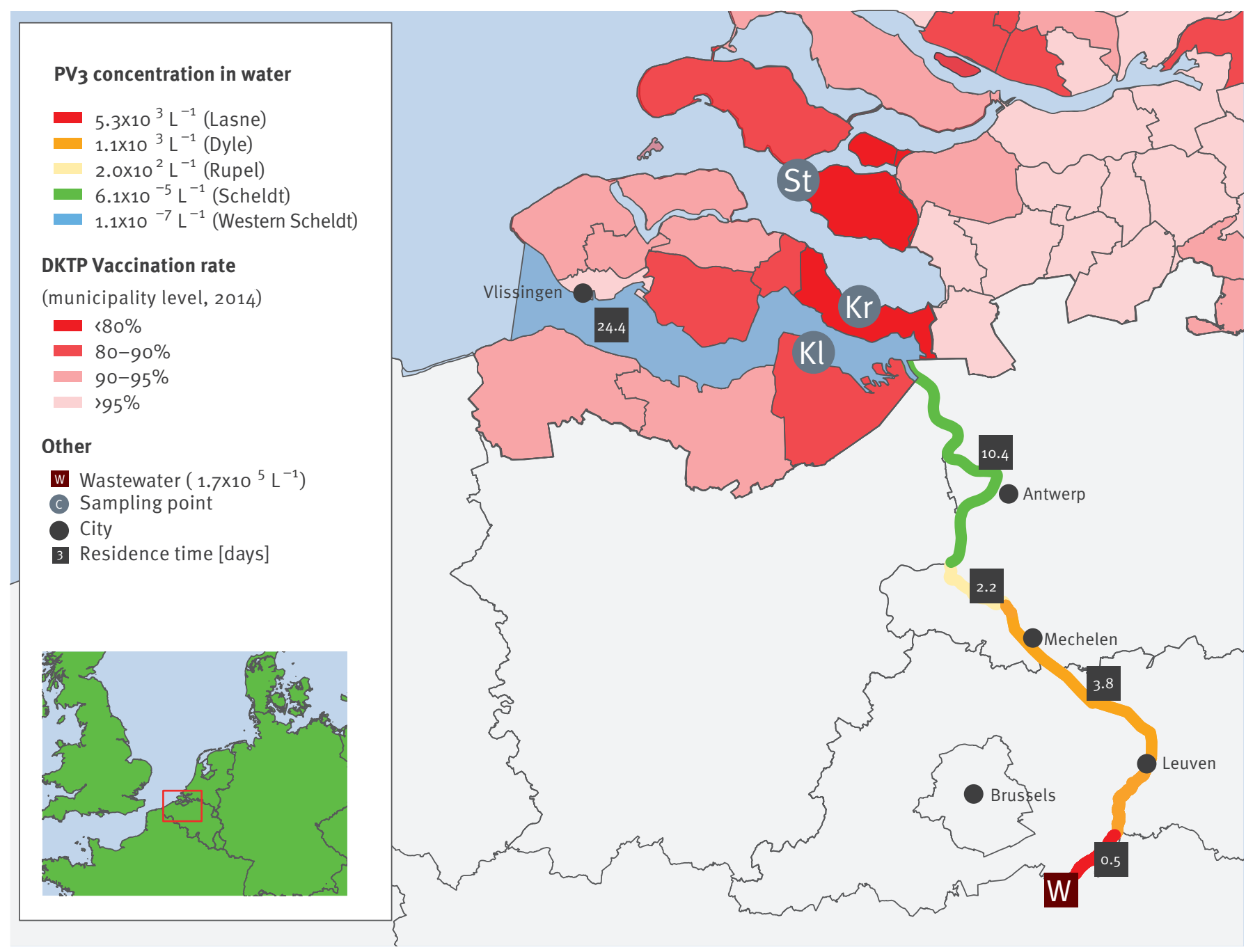

DKTP: diphtheria, pertussis (Dutch: kinkhoest), tetanus, and polio; Kl: mussel sampling site, Kloosterzande, the Netherlands; Kr: sewage sampling site Krabbendijke, the Netherlands; PV3: poliovirus type 3; St: sewage sampling site Stavenisse, the Netherlands; W: wastewater treatment plant, Rosières, Belgium.

Source for vaccination coverage data: [15].

by light microscopy every working day following inoculation for at least seven days.

\section{RNA extraction and RT-PCR for detection of poliovirus RNA}

Viral RNA was extracted from $200 \mu \mathrm{L}$ concentrated water samples, extracted sludge or sediment, mussel homogenate or cell cultures using the MagNAPure LC total nucleic acid isolation kit with a MagNAPure LC instrument as described [21]. Enterovirus RNA was amplified by semi-nested enterovirus RT-PCR (snEVRT-PCR, PCR1) as described by Nix et al. [22]. If samples were negative, they were retested after 10 times dilution to reduce inhibition. In addition, a subset of samples, including all samples positive in PCR 1, was analysed by Intravacc (biopharmaceutical company developing vaccines, formerly part of RIVM) using an RT-PCR specific for poliovirus type 3 Saukett strains G/H (PCR 2) according to Nijst et al. [23].

\section{Results}

Consultation and qualitative risk assessment On 8 September, the consequences for the Dutch population based on a qualitative risk assessment were discussed by the Dutch response team (Figure 1). It was concluded that given the release of $10^{13}$ infectious WPV 3 particles, significant numbers of infectious polioviruses were likely to be passing through the Belgium rivers, that infectious poliovirus could enter the Dutch waters, that contact with contaminated water could not be excluded and that silent transmission in the Belgian 
TABLE 1

Estimated particle travel times, dilution factors concentrations and risk of infection by swimming in different water bodies in Belgium and the Netherlands following an accidental release of poliovirus in Belgium, September-October 2014

\begin{tabular}{|c|c|c|c|c|c|}
\hline Water body & $\begin{array}{l}\text { Travel or } \\
\text { residence time (days) }\end{array}$ & $\begin{array}{c}\text { Dates of } \mathrm{WPV}_{3} \\
\text { arrival }\end{array}$ & Dilution factor & $\begin{array}{c}\text { WPV } 3 \text { concentration } \\
n / L\end{array}$ & $\begin{array}{c}\text { Risk of infection per child } \\
\text { per event }\end{array}$ \\
\hline $\begin{array}{l}\text { Wastewater treatment } \\
\text { plant }\end{array}$ & 0.92 & 2-3 Sep & $2.6 \times 10^{5}$ & $1.7 \times 10^{5}$ & NR \\
\hline Lasne & 0.5 & 3 Sep & 4 & $5.3 \times 10^{3}$ & 0.86 \\
\hline Dyle & 3.8 & 10 Sep & 3 & $1.1 \times 10^{3}$ & 0.77 \\
\hline Dyle at Rumst & 0 & 10 Sep & 2 & $5.3 \times 10^{2}$ & 0.72 \\
\hline Rupel & 2.2 & 12 Sep & 2 & $2.0 \times 10^{2}$ & 0.61 \\
\hline $\begin{array}{l}\text { Western Scheldt at } \\
\text { Belgian-Dutch border }\end{array}$ & 10.4 & 23 Sep & $8 \times 10^{5}$ & $6.1 \times 10^{-5}$ & $8.0 \times 10^{-7}$ \\
\hline $\begin{array}{l}\text { Western Scheldt near } \\
\text { Vlissingen }\end{array}$ & 14 & $60 \mathrm{ct}$ & $4.4 \times 10^{6}$ & $1.1 \times 10^{-7}$ & $1.4 \times 10^{-9}$ \\
\hline
\end{tabular}

NR: not relevant.

a Per child was chosen because children are more likely to swim and more likely to be infected with poliovirus after exposure.

\section{TABLE 2}

Risk of infection with wild poliovirus type 3 per person per event in the Netherlands (shellfish consumption or swimming) following an accidental release of poliovirus in Belgium, September-November 2014

Western Scheldt at Belgian-Dutch border

Western Scheldt near Vlissingen

\begin{tabular}{|c|c|c|c|c|}
\hline & \multicolumn{2}{|c|}{ Western Scheldt at Belgian-Dutch border } & \multicolumn{2}{|c|}{ Western Scheldt near Vlissingen } \\
\hline & \multicolumn{4}{|c|}{ Risk of infection } \\
\hline \multicolumn{5}{|c|}{ Consumption of raw shellfish } \\
\hline Shellfish consumption & $100 \times$ concentrated $^{a}$ & $1,000 \times$ concentrated $^{a}$ & $100 \times$ concentrated $^{a}$ & $1,000 \times$ concentrated $^{a}$ \\
\hline $10 \mathrm{~g}$ & $2.2 \times 10^{-5}$ & $2.2 \times 10^{-4}$ & $3.9 \times 10^{-8}$ & $3.9 \times 10^{-7}$ \\
\hline $15 \mathrm{~g}$ & $3.2 \times 10^{-5}$ & $3.2 \times 10^{-4}$ & $5.9 \times 10^{-8}$ & $5.9 \times 10^{-7}$ \\
\hline $150 \mathrm{~g}$ & $3.2 \times 10^{-4}$ & $3.2 \times 10^{-3}$ & $5.9 \times 10^{-7}$ & $5.9 \times 10^{-6}$ \\
\hline $350 \mathrm{~g}$ & $7.5 \times 10^{-4}$ & $7.5 \times 10^{-3}$ & $1.4 \times 10^{-6}$ & $1.4 \times 10^{-5}$ \\
\hline \multicolumn{5}{|l|}{ Swimming event } \\
\hline Man & \multicolumn{2}{|c|}{$5.8 \times 10^{-7}$} & \multicolumn{2}{|c|}{$1.1 \times 10^{-9}$} \\
\hline Woman & \multicolumn{2}{|c|}{$3.9 \times 10^{-7}$} & \multicolumn{2}{|c|}{$7.0 \times 10^{-10}$} \\
\hline Child & \multicolumn{2}{|c|}{$8.0 \times 10^{-7}$} & \multicolumn{2}{|c|}{$1.4 \times 10^{-9}$} \\
\hline
\end{tabular}

a $100 \times$ and $1,000 \times$ concentrated represent two different scenarios, in which the shellfish concentrated the virus particles from the surrounding waters by a factor of 100 or 1,000 .

population could not be excluded. Furthermore, a QMRA was needed to support decision making on preventive measures for the Western Scheldt area. Along the Western Scheldt coast are some designated swimming areas. During swimming, water may be swallowed and oral ingestion is an efficient infection route for poliovirus. Therefore, a QMRA for poliovirus infection by swimming was included. Oysters and mussels are not harvested commercially in the Western Scheldt but harvesting for private use is permitted. Because bivalve molluscs concentrate enteric viruses from their growing waters, it was decided to include poliovirus in shellfish in the QMRA.

Contamination of commercial oyster growing areas in the nearby Eastern Scheldt was highly unlikely, because the net water flow is small and mostly from the
Eastern Scheldt to the Western Scheldt (Scheldt-Rhine Canal). It was concluded that commercial shellfish harvesting was not affected. No commercial harvesting of samphire and aster occurs in the Western Scheldt, and the samphire harvesting season was ending. Uptake and possible concentration of infectious poliovirus by the plants is not described in the literature. Therefore, samphire and aster consumption was not considered as a risk. Shrimps harvested from the Western Scheldt are boiled immediately on the boat and cooled down using Western Scheldt water. Because there is no concentration of virus particles in the boiled shrimps from this cooling water, they were not considered relevant. The involved surface waters are not used for irrigation or drinking water production. 


\section{Quantitative microbial risk assessment}

Estimated WPV3 concentrations in water bodies

The limits of detection for the water samples at the time of sampling were between $2 \times 10^{2}$ and $1 \times 10^{3}$ infectious polioviruses per litre. The limit of detection in mussels was one infectious poliovirus per mussel.

Estimated $\mathrm{WPV}_{3}$ concentrations in the water bodies are listed in Table 1 and shown in Figure 4. Dilution factors in the first four water bodies after the WWTP are small; hence, estimated concentrations are high and easily detectable when sampled at the appropriate moments. Even if removal by sewage treatment had been $2 \log _{10}$ instead of $0.7 \log _{10}, W P V_{3}$ would have been detectable. In the large saline water bodies with tidal effects near Antwerp, the dilution factors are large, dropping estimated WPV 3 concentrations many orders in magnitude. The longer residence times in the large water bodies account for additional inactivation.

\section{Estimated poliovirus concentration in the WWTP} effluent and sediment relative to the limits of detection Parameters used included the concentration factors of our method, volumes /quantity of sludge/sediment/ number of mussels analysed, the detection limit of the culture method (one infectious poliovirus per $100 \mu \mathrm{L}$ concentrated and pretreated sample per culture tube) and the inactivation rates for storage time-temperature combinations to estimate the limit of detection in the original samples. The sediment samples should have contained more than 2-20 infectious polioviruses per gram sediment/sludge at the time of sampling to be detected with the methods used. The limit of detection in mussels was one infectious poliovirus per mussel.

The estimated WPV 3 concentration in the WWTP effluent on 3 September 2014 was $1.7 \times 10^{5} \mathrm{WPV}_{3} / \mathrm{L}$ for the low treatment scenario $\left(0.7 \log _{10}\right)$ (Table 1$)$ and $8 \times 10^{3}$ $W P V_{3} / L$ in the case of $2 \log _{10}$ reduction by the treatment. Based on mixing in the WWTP, WPV 3 concentrations in the effluent were expected to decline at a rate of $4 \log _{10}$ per seven days. The poliovirus concentration on 3 September in the quiescent basin was estimated to be from $8 \times 10^{3}$ to $170 \times 10^{3}$ per litre water, well above the detection limit of 700 polioviruses per litre on the date of analysis. Samples collected on 6 September were estimated to contain more than $10^{2}$ infectious polioviruses per gram sediment at the time of sampling and consequently, more than 10 poliovirus particles per gram sediment at the time of analysis.

\section{Estimation of infection risks, intervention measures and communication}

As indicated in Table 1, the estimated infection risk from swimming in the Belgian rivers was high (>50\%). However, these results only became available when the estimated virus concentrations had decreased considerably. The counter measures implemented by the Belgian authorities were focused at the river Lasne only. None of the waters downstream of the WWTP were used for irrigation or drinking water production.

It was calculated that the polioviruses would not reach the Dutch waters before 18 September (Figure 1). Swimming in the Western Scheldt was estimated not to be a high risk activity. The estimated infection risk from consuming poliovirus-contaminated raw shellfish from the eastern part of the Western Scheldt corresponded to 3.2 infections per 10,000 people (Table 2). The estimated infection risk from shellfish consumption harvested in the Western part of the Western Scheldt was low $\left(\ll 1.5 \times 10^{-5}\right)$. Based on these estimates, the Dutch response team advised on 21 September "to heat shellfish harvested in the western part of the Western Scheldt in boiling water for at least 90 seconds" from 22 September onwards. The cooking advice was published on the website of the RIVM and the Dutch Food safety authority and sent to the local public health services in Zeeland. At several locations along the Western Scheldt, signs were placed informing about possible poliovirus contamination and the cooking advice. It was noticed and covered online by several national and local newspapers on the same day (21 September), including the Reformatorisch Dagblad, the daily newspaper for the orthodox reformed community in the Netherlands. The advice was also communicated to WHO/Europe and ECDC.

\section{Virus detection}

In the samples collected in or close to the WWTP in Rosières, Belgium, no infectious poliovirus was detected using culture on L2ob cells and no poliovirus RNA was detected using the snEV-RT-PCR or the poliovirus type 3 Saukett strain-specific RT-PCR (Table 3). Several RD and Ht-29 cell cultures showed CPE after inoculation, and different echoviruses and a human coxsackie A virus were detected. Several of the cultured samples yielded mixed sequences. Because poliovirus exclusion was the goal of these experiments, no further attempts were made to obtain additional sequencing information. In the schedule applied, it took seven days after arrival of a sample at the RIVM to obtain snEV-RT-PCR results and 10 days to obtain the L2ob culture results.

No infectious poliovirus and no poliovirus RNA were detected in the mussels and $77 \%$ of the samples were negative for enterovirus, but twice an echovirus type 25 was detected, once an echovirus type 11 and four times a non-polio enterovirus.

All 19 sewage samples collected in Stavenisse and Krabbendijke were negative for poliovirus but positive for other enteroviruses. Echovirus type 18 was found in four of nine samples from Krabbendijke and echovirus type 20 was found in six of 10 samples from Stavenisse. Coxsackievirus types $\mathrm{A}_{2}$ and $\mathrm{B}_{5}$ and $\mathrm{ECHO}$-virus types 3, 6 and 11 were also detected. No polioviruses were detected in sewage samples taken in the same period for the regular surveillance programme for exclusion of 
TABLE 3

Characteristics and laboratory analysis of samples collected at the wastewater treatment plant, Rosières, Belgium, September $2014(\mathrm{n}=18)$

\begin{tabular}{|c|c|c|c|c|c|c|c|c|c|c|}
\hline $\begin{array}{l}\text { Sampling } \\
\text { site }\end{array}$ & $\begin{array}{l}\text { Type of } \\
\text { sample }\end{array}$ & $\begin{array}{l}\text { Sampling date } \\
\text { (dd/mm/yyyy) }\end{array}$ & $\begin{array}{l}\text { Start of processing } \\
\text { (dd/mm/yyyy) }\end{array}$ & $\begin{array}{l}\text { Volume } \\
\text { (mL) }\end{array}$ & Treatment & $\begin{array}{l}\text { Culture } \\
\text { on } L 20 B \\
\text { cells }\end{array}$ & $\begin{array}{l}\text { Culture on } \\
\text { RD/Ht-29 } \\
\text { cells }\end{array}$ & $\begin{array}{l}\text { PCR } \\
1^{\mathrm{a}}\end{array}$ & $\begin{array}{c}\mathrm{PCR} \\
2\end{array}$ & EV typing \\
\hline GSK plant & Water $^{\mathrm{b}}$ & $2 / 9 / 2014$ & $13 / 10 / 2014$ & 500 & $\begin{array}{c}\text { Conc to }<3 \\
\mathrm{~mL}\end{array}$ & Neg & Neg & $\operatorname{Pos}^{c}$ & $\mathrm{Neg}$ & NPEV $^{d}$ \\
\hline $\begin{array}{l}\text { WWTP } \\
\text { entrance }\end{array}$ & Water & $2 / 9 / 2014$ & $11 / 10 / 2014$ & 900 & $\begin{array}{c}\text { Conc to }<3 \\
\mathrm{~mL}\end{array}$ & Neg & Pos & Pos & Neg & $\begin{array}{c}\text { Echovirus type } \\
11\end{array}$ \\
\hline $\begin{array}{l}\text { WWTP } \\
\text { exit }\end{array}$ & Water ${ }^{\mathrm{b}}$ & $2 / 9 / 2014$ & $11 / 10 / 2014$ & 900 & $\begin{array}{c}\text { Conc to }<3 \\
\mathrm{~mL}\end{array}$ & Neg & Neg & Pos & Neg & NPEV $^{d}$ \\
\hline $\begin{array}{l}\text { WWTP } \\
\text { entrance }\end{array}$ & Water & $3 / 9 / 2014$ & $16 / 9 / 2014$ & 100 & $\begin{array}{c}\text { Conc to }<2 \\
\mathrm{~mL}\end{array}$ & Neg & ND & Pos & Neg & $\begin{array}{l}\text { Echovirus } \\
\text { type } 9\end{array}$ \\
\hline $\begin{array}{l}\text { WWTP } \\
\text { basin }\end{array}$ & Water & $3 / 9 / 2014$ & $11 / 10 / 2014$ & 500 & $\begin{array}{c}\text { Conc to }<3 \\
\mathrm{~mL}\end{array}$ & Neg & Neg & Pos & $\mathrm{Neg}$ & $\mathrm{NPEV}^{\mathrm{d}}$ \\
\hline $\begin{array}{l}\text { WWTP } \\
\text { basin }\end{array}$ & Water & $3 / 9 / 2014$ & $11 / 10 / 2014$ & 500 & $\begin{array}{c}\text { Conc to }<3 \\
\mathrm{~mL}\end{array}$ & Neg & Pos & Pos & Neg & $\mathrm{NPEV}^{\mathrm{d}}$ \\
\hline $\begin{array}{l}\text { WWTP } \\
\text { exit }\end{array}$ & Water & $3 / 9 / 2014$ & $16 / 9 / 2014$ & 100 & $\begin{array}{c}\text { Conc to }<2 \\
\mathrm{~mL}\end{array}$ & Neg & Neg & Neg & $\mathrm{Neg}$ & ND \\
\hline $\begin{array}{l}\text { WWTP } \\
\text { entrance }\end{array}$ & Water & $4 / 9 / 2014$ & $11 / 10 / 2014$ & 500 & $\begin{array}{c}\text { Conc to }<3 \\
\mathrm{~mL}\end{array}$ & Neg & Neg & Pos & Neg & $\begin{array}{l}\text { Echovirus } \\
\text { type } 3\end{array}$ \\
\hline $\begin{array}{l}\text { WWTP } \\
\text { exit }\end{array}$ & Water & $4 / 9 / 2014$ & $11 / 10 / 2014$ & 500 & $\begin{array}{c}\text { Conc to }<3 \\
\mathrm{~mL}\end{array}$ & Neg & Neg & Pos & $\mathrm{Neg}$ & $\mathrm{NPEV}^{\mathrm{d}}$ \\
\hline $\begin{array}{l}\text { WWTP } \\
\text { entrance }\end{array}$ & Water & $5 / 9 / 2014$ & $16 / 9 / 2014$ & 100 & $\begin{array}{c}\text { Conc to }<2 \\
\mathrm{~mL}\end{array}$ & Neg & ND & Neg & Neg & ND \\
\hline $\begin{array}{l}\text { WWTP } \\
\text { exit }\end{array}$ & Water & $5 / 9 / 2014$ & $16 / 9 / 2014$ & 100 & $\begin{array}{c}\text { Conc to }<2 \\
\mathrm{~mL}\end{array}$ & Neg & ND & Neg & Neg & ND \\
\hline $\begin{array}{l}\text { WWTP } \\
\text { entrance }\end{array}$ & Water & $5 / 9 / 2014$ & $13 / 10 / 2014$ & 400 & $\begin{array}{c}\text { Conc to }<3 \\
\mathrm{~mL}\end{array}$ & Neg & Pos & Pos & Neg & $\begin{array}{c}\text { Echovirus type } \\
11 \\
\end{array}$ \\
\hline $\begin{array}{l}\text { WWTP } \\
\text { exit }\end{array}$ & Water & $5 / 9 / 2014$ & $13 / 10 / 2014$ & 400 & $\begin{array}{c}\text { Conc to }<3 \\
\mathrm{~mL}\end{array}$ & Neg & Neg & Pos & Neg & NPEV $^{d}$ \\
\hline $\begin{array}{l}\text { WWTP } \\
\text { basin }\end{array}$ & Water & $6 / 9 / 2014$ & $16 / 9 / 2014$ & 500 & $\begin{array}{c}\text { Conc to }<5 \\
\mathrm{~mL}\end{array}$ & Neg & Neg & Neg & Neg & ND \\
\hline $\begin{array}{l}\text { WWTP } \\
\text { basin }\end{array}$ & Sludge & $6 / 9 / 2014$ & $16 / 9 / 2014$ & NA & Extracted & Neg & ND & Neg & Neg & ND \\
\hline $\begin{array}{l}\text { WWTP } \\
\text { entrance }\end{array}$ & Sediment & $9 / 9 / 2014$ & $10 / 9 / 2014$ & NA & Extracted & Neg & ND & Pos & Neg & NPEV $^{d}$ \\
\hline $\begin{array}{l}\text { WWTP } \\
\text { exit }\end{array}$ & Sediment & 9/9/2014 & $10 / 9 / 2014$ & NA & Extracted & Neg & ND & Pos & Neg & $\begin{array}{c}\text { Coxsackievirus } \\
\text { A type } 9 \\
\end{array}$ \\
\hline $\begin{array}{l}\text { WWTP } \\
\text { basin }\end{array}$ & Sludge & $18 / 9 / 2014$ & 19/9/2014 & NA & Extracted & Neg & ND & Pos & ND & NPEV $^{d}$ \\
\hline
\end{tabular}

Conc: concentrated; GSK: GlaxoSmithKline; EV: enterovirus; NA: not applicable; ND: not determined; Neg: negative; NPEV: non-polio enterovirus; Pos: positive; WWTP: wastewater treatment plant.

a PCR1 was performed on RNA extracted from the concentrated samples or form the RD/Ht-29 cultures.

b Pooled samples, collected over a 24 hour period.

c Cultures of RD/Ht29 were analysed by PCR, independent of cytopathic effect.

${ }^{d}$ No growth on L2OB cells, positive for enterovirus RNA by PCR1, but sequencing did not yield a typable sequence because of insufficient RNA (weak band on blot) or (most often) mixed infection.

poliovirus circulation in the Dutch Bible belt (data not shown).

On 21 November, it was made public that no poliovirus had been found in the water, sludge and sediment samples, nor in the mussels harvested in the eastern part of the Western Scheldt, and that no circulation of poliovirus had been found in the two communities in Zeeland. On the same day, the warning signs along the Western Scheldt were removed.

\section{Discussion}

No infectious poliovirus was detected using culture methods and no poliovirus RNA was detected using molecular methods in any of the samples. Based on calculations presented in this paper, at least the WWTP basin and the effluent samples from 3,4 and 5 September were expected to contain detectable numbers of viruses after the release of $10^{13}$ infectious polioviruses into the WWTP. The discrepancy between the laboratory results and the reported release does, however, not diminish the relevance of this risk assessment exercise. 
Complete mixing of the WPV 3 suspension in the WWTP and only a $0.7 \log _{10}$ reduction by treatment were assumed. Higher reductions by the WWTP can occur when viruses attach well to solid surfaces. Generally, polioviruses have an isoelectric point near neutral $\mathrm{pH}$ and attach well to solid surfaces $[24,25]$. However, $W V_{3}$ Saukett strain has an isoelectric point of 5.8 [26] and may therefore remain in suspension in wastewater and during its transport in river water. Estimates for poliovirus concentrations in the wastewater effluent were made assuming primary and secondary sewage treatment only. If membrane ultrafiltration had been performed on $100 \%$ of the wastewater, an additional reduction of more than $4 \log _{10}$ could have been achieved by the WWTP [27] and consequently, poliovirus concentrations in the effluent would have peaked on 3 September at six WPV 3 per litre and decreased after that. A more likely scenario with ca $50 \%$ of the water treated by membrane ultrafiltration would result in an additional reduction of only $0.3 \log _{10}$. To conclude, the estimated numbers of WPV 3 particles that were discharged by the WWTP may have been overestimated.

For estimating infection risks, the beta-Poisson dose response model of $\mathrm{WPV}_{3}$ Fox in newborn infants was used [14]. Dose response data also exist for $W^{2} V_{3}$ Fox in premature infants and for poliovirus type $1 \mathrm{SM}$ in adults. In Figure 2, these dose response curves are compared with the probability of exposure. All dose response curves were very close to each other and not far below the exposure probability line (indicating that every exposure leads to infection). This demonstrates that polioviruses are highly infectious: exposure to only a few WPV 3 particles may suffice to cause an infection and consequently virus multiplication, shedding and spreading $[28,29]$. Given this knowledge, choosing the dose response data of $W V_{3}$ Fox in newborn infants was justified.

We cannot explain the lack of poliovirus detections: in several samples, the estimated WPV 3 concentrations were well above the limit of detection for poliovirus enteroviruses were detected and in these samples. At several steps, the sensitivity for detection of infectious poliovirus could have been increased. The samples taken directly following the release were sent to the WHO Specialised Laboratory for Polio in the Netherlands for analysis after 10 to 40 days of storage at $2-8{ }^{\circ} \mathrm{C}$. Even though poliovirus is a stable nonenveloped virus, this will have resulted in some loss of infectivity. In addition, larger volumes of water and sludge from the first days could have been collected.

The QMRA concluded that shellfish consumption could lead to infection of more than one in 10,000 persons consuming raw shellfish. Even though the Western Scheldt is not a commercial shellfish harvesting area, this was considered an unacceptable risk and consequently, a shellfish cooking advice was issued. Not detecting a poliovirus in the 150 mussels we tested was expected at these low levels of contamination.
The risk of infection (>50\%) estimated for swimming in the Belgian rivers from 3 to 12 September was considered high. Nevertheless, the statement by the Belgium's High Council of Public Health that the risk of a person developing polio after contact with the contaminated waters was "extremely small" was true because less than $1 \%$ of non-vaccinated persons will develop polio after infection, and this percentage is even lower for vaccinated persons. However, an accidental release of this magnitude may be considered a real threat for poliovirus eradication. It is important to realise that enormous quantities of water are required to dilute a release of $10^{13}$ infectious wild poliovirus to negligible poliovirus concentrations and an acceptable risk of infection, quantities of water that are not readily available in small rivers.

The Belgian authorities cooperated well, and information requests to WIV-ISP were dealt with appropriately. There was no legal obligation for the Belgian authorities to report the release of poliovirus to the Dutch authorities since the accident happened at a location from which it takes more than two days for the contamination to reach the country's borders (Convention of Helsinki, 1992 [30]). In addition, as no infectious poliovirus was found there was no obligation to report to WHO. Nevertheless, the current paper describes a risk assessment that ideally should have been performed by all vaccine production facilities before starting up large-scale culture of WPV, to evaluate consequences of accidental poliovirus release into the environment (see also GAPIII [6]). Such a risk assessment may be used immediately in case an accident occurs and provide the basis for immediate actions such as risk communication, preventive measures and risk-based monitoring involving independent experts.

Appropriate data on water quantities and dilutions on the whole trajectory were difficult to obtain because only average values were available, while it was unusually dry during the weeks following the accident. In addition, different models used by different institutes resulted in a broad range of dilution factors in the tidal area. Therefore, input data for the QMRA changed several times. In fact, a risk assessment based on data available on 15 September was issued on 18 September and did not result in implementation of any measures because the infection risk in Dutch waters or via shell fish consumption never exceeded $1 \times 10^{-4}$. On 21 September, new data, supported by a wider consensus, were provided and the QMRA was conducted again on that day, which resulted in the risk estimates presented in this paper. In a period with average or high rainfall, the virus would be diluted more in the Belgium rivers and the risk of infection would be lower. Extreme rainfall causing sewage overflow at the time of an accidental release could result in a higher number of viruses released into the river Lasne. We assumed a worst-case scenario with only $80 \%$ of the viruses removed by the WWTP, and even in a scenario with sewage overflow, the extra dilution in the river Lasne 
would have reduced the infection risk (by the transmission routes studied).

Preventive measures were implemented just before the front of the poliovirus contamination was estimated to reach the Belgian-Dutch border (on 23 September) and warning signs could be placed in time. Because the messages on the RIVM website were noticed and published by local and national news sites within a day, it was concluded that the communication concerning this accident was proportional and the population at risk had been reached.

Based on our experience presented here and the time needed for detection of infectious poliovirus, surveillance for live poliovirus in surface waters downstream of polio vaccine production plants is unlikely to be timely or efficient. Adequate safeguards in the production process minimising the risk of infectious virus release and adequate wastewater treatment on site, are more likely to be a safe strategy. In addition, this specific WWTP is equipped for tertiary water treatment by ultrafiltration with a high capacity. Applying the ultrafiltration to all wastewater taken on 2 and 3 September would have reduced the estimated infection risks for swimming in the Lasne from $86 \%$ to less than $5 \%$.

We conclude that the reported release of $10^{13}$ infectious poliovirus particles has not resulted in the expected detectable levels of poliovirus in any of the samples from Belgium and the Netherlands taken after the incident. No signs for poliovirus circulation in the two Zeelandic communities sampled or in the Dutch Bible belt were found. The reported release of poliovirus type 3 Saukett strain by the vaccine production plant did not result in poliovirus circulation in the Netherlands in the period from 2 September to 7 November 2014. This risk assessment following the accidental release of WPV by the poliovirus vaccine production plant showed that relevant data on water flows were not readily available and that prior assumptions of dilution factors were highly overestimated. A QMRA should have been performed by all vaccine production facilities before starting up large-scale culture of WPV in order to be able to implement effective interventions when an accident happens.

\section{Acknowledgements}

We thank the following individuals for their contribution: Ron Altena, Dani Atto, Harrie van der Avoort, Anne- Marie van den Brandt, Jeroen Cremer, Edin Jusic, Jeroen van Leuken, Froukje Lodder, Willemijn Lodder, Helma Ruijs, Aura Timen, Bas van der Veer (RIVM, Clb); Pepijn Morgenstern and Annemarie van Wezel (Crisis Expert Team Environment and Drinking water, the Netherlands); Jaap van Steenwijk (Department of Waterways and Public Works, RWS, the Netherlands); Dick Amesz (DCMR Environmental Services Rijnmond, the Netherlands); Jeroen Wijsman (IMARES Wageningen UR, the Netherlands); Jacobine van den Boomgaard (Dutch Food Safety Authority, the Netherlands); Bernard Metz and Justin de Ridder (Intravacc, the Netherlands). We thank Marc van
Ranst (Catholic University of Leuven, Belgium) for sample collection, and the Biosafety and Biotechnology Unit of the Scientific Institute of Public Health, Brussels, Belgium for sample information and shipment, and Eugene Gavrilin (WHO Euro, Stockholm, Denmark) for critically reviewing the manuscript and facilitating international sample shipments. This work was funded by the Ministry of Health, Welfare and Sport, the Netherlands.

\section{Conflict of interest}

None declared.

\section{Authors' contributions}

Erwin Duizer conceived the study, analysed the data and wrote the manuscript. Saskia Rutjes contributed to the risk assessment, organized the mussel sample analysis and provided comments on the manuscript. Ana Maria de Roda Husman participated in data analysis and interpretation and provided comments on the manuscript. Jack Schijven performed the QMRA and provided comments on the manuscript.

\section{References}

1. European Centre for Disease Prevention and Control (ECDC). The accidental release of 45 litres of concentrated live polio virus solution into the environment - Belgium. In: Monitoring current threats: ECDC Communicable Disease Threats Report (CDTR), week 37/2014. Stockholm: ECDC; 2014. Available from: http://ecdc.europa.eu/ en/press/news/ layouts/forms/News DispForm. aspx? List $=8 \mathrm{db} 7286 \mathrm{c}-\mathrm{fe} 2 \mathrm{~d}-476 \mathrm{c}-9133-18 \mathrm{ff} 4 \mathrm{cb} 1 \mathrm{~b} 568 \& \mathrm{ID}=1065$

2. Shulman LM, Gavrilin E, Jorba J, Martin J, Burns CC, Manor $Y$, et al. Molecular epidemiology of silent introduction and sustained transmission of wild poliovirus type 1, Israel, 2013. Euro Surveill. 2014;19(7):20709.DOI: 10.2807/1560-7917. ES2014.19.7.20709 PMID: 24576471

3. Bertrand I, Schijven JF, Sánchez G, Wyn-Jones P, Ottoson J, Morin T, et al. The impact of temperature on the inactivation of enteric viruses in food and water: a review. J Appl Microbiol. 2012;112(6):1059-74.DOI: 10.1111/j.1365-2672.2012.05267.x PMID: 22380614

4. Greening G. Human and animal viruses in food. In: Viruses in foods. Ed. Goyal. Springer 2006.

5. McLeod C, Hay B, Grant C, Greening G, Day D. Localization of norovirus and poliovirus in Pacific oysters.J Appl Microbiol. 2009;106(4):1220-30.DOI: 10.1111/j.1365-2672.2008.04091.X PMID: 19187161

6. World Health Organization (WHO). GAPIII. WHO global action plan to minimize poliovirus facility-associated risk after type-specific eradication of wild polioviruses and sequential cessation of OPV use. Geneva: WHO; 2015. Available from: http://www.polioeradication.org/Portals/o/Document/ Resources/PostEradication/GAPIII 2015.pdf

7. Khetsuriani N, Pfeifer D, Deshevoi S, Gavrilin E, Shefer A, Butler R, et al. Challenges of maintaining polio-free status of the European Region. J Infect Dis. 2014;210(Suppl 1):S194-207. DOI: 10.1093/infdis/jiu096 PMID: 25316836

8. Lodder WJ, de Roda Husman AM. Presence of noroviruses and other enteric viruses in sewage and surface waters in The Netherlands.Appl Environ Microbiol. 2005;71(3):1453-61.DOI: 10.1128/AEM.71.3.1453-1461.2005 PMID: 15746348

9. Dowdle WR, Birmingham ME. The biologic principles of poliovirus eradication.J Infect Dis. 1997;175(Suppl 1):S286-92. DOI: 10.1093/infdis/175.Supplement_1.S286 PMID: 9203732

10. Schijven JF, Teunis PF, Rutjes SA, Bouwknegt M, de Roda Husman AM. QMRAspot: a tool for Quantitative Microbial Risk Assessment from surface water to potable water.Water Res. 2011;45(17):5564-76.DOI: 10.1016/j.watres.2011.08.024 PMID: 21885080

11. Lodder WJ, Schijven JF, Rutjes SA, de Roda Husman AM, Teunis PF. Entero- and parechovirus distributions in surface water and probabilities of exposure to these viruses during water recreation.Water Res. 2015;75:25-32.DOI: 10.1016/j. watres.2015.02.024 PMID: 25746959

12. Schets FM, Schijven JF, de Roda Husman AM. Exposure assessment for swimmers in bathing waters and swimming 
pools.Water Res. 2011;45(7):2392-400.DOI: 10.1016/j. watres.2011.01.025 PMID: 21371734

13. Bouwknegt $M$, Verhaelen $K$, de Roda Husman AM, Rutjes SA. Quantitative risk profile for viruses in foods. Report 330371008. Bilthoven: National Institute for Public Health and the Environment (RIVM); 2013. Available from: http://www.rivm.nl/en/Documents_ and_publications/Scientific/Reports/2013/mei/ Quantitative risk profile for viruses in foods

14. Teunis PFM, Havelaar AH. The dose-response relation in human volunteers for gastro-intestinal pathogens. Report 284550002. Bilthoven: National Institute for Public Health and the Environment (RIVM); 1996. Available from: http://www.rivm. nl/en/Documents_and_publications/Scientific/Reports/1996/ april/The_dose_response_relation_in_human_volunteers_for gastro intestinal pathogens? sp $=\mathrm{cml}_{2}$ bXE9ZmFsc2U $7 \mathrm{c}_{2} \mathrm{VhcmN}$ oYmFzZ̄To2NDc5MDtyaXZtcT1mYWxzZTs=\&pagenr $=6480$

15. DKTP vaccinaties, verslagjaar 2014. [DPTP vaccinations, reporting year 2014]. Bilthoven: National Institute for Public Health and the Environment (RIVM); 2014. Dutch. Available from: http://www.zorgatlas.nl/preventie/ vaccinaties-en-screening/dktp-per-gemeente/\#breadcrumb

16. Skraber S, Schijven J, Italiaander R, de Roda Husman AM. Accumulation of enteric bacteriophage in fresh water sediments.J Water Health. 2009;7(3):372-9.DOI: 10.2166/ wh.2009.098 PMID: 19491489

17. Microbiology of food and animal feed -- Horizontal method for determination of hepatitis A virus and norovirus in food using real-time RT-PCR; ISO/TS 15216. Geneva: ISO; 2013. Available from: http://www.iso.org/iso/home/store/catalogue_ics/ catalogue_detail_ics.htm?csnumber $=55382$

18. Pipkin PA, Wood DJ, Racaniello VR, Minor PD. Characterisation of $L$ cells expressing the human poliovirus receptor for the specific detection of polioviruses in vitro.J Virol Methods. 1993;41(3):333-40.DOI: 10.1016/0166-0934(93)90022-J PMID: 8386181

19. Wecker I, ter Meulen V. RD cells in the laboratory diagnosis of enteroviruses. Med Microbiol Immunol. 1977;163(4):233-40. DOI: 10.1007/BF02125507 PMID: 203835

20. Duizer E, Benschop K, Uslu G, Jusic E, Schalk M, Koen G, et al. Verleden, heden en toekomst van de enterovirus en parechovirus diagnostiek en surveillance in Nederland. Ned Tijdschr Med Microbiol. 2013;21(2):50-5.

21. van der Sanden $\mathrm{S}$, de Bruin $\mathrm{E}$, Vennema $\mathrm{H}$, Swanink $\mathrm{C}$, Koopmans $M$, van der Avoort $H$. Prevalence of human parechovirus in the Netherlands in 2000 to 2007.J Clin Microbiol. 2008;46(9):2884-9.DOI: 10.1128/JCM.00168-08 PMID: 18614653

22. Nix WA, Oberste MS, Pallansch MA. Sensitive, seminested PCR amplification of VP1 sequences for direct identification of all enterovirus serotypes from original clinical specimens.J Clin Microbiol. 2006;44(8):2698-704.DOI: 10.1128/JCM.00542-06 PMID: 16891480

23. Nijst OE, Mouthaan JJ, Mekkes DR, Jusic E, van der Avoort HG, Metz B. Rapid and accurate identification of poliovirus strains used for vaccine production.J Virol Methods. 2013;189(1):18995.DOI: 10.1016/j.jviromet.2013.01.026 PMID: 23434540

24. Schijven JF, Hassanizadeh SM. Removal of viruses by soil passage: Overview of modeling, processes, and parameters. Crit Rev Environ Sci Technol. 2000;30(1):49-127. DOI: $10.1080 / 10643380091184174$

25. Schijven JF, de Bruin HA, Hassanizadeh SM, de Roda Husman AM. Bacteriophages and Clostridium spores as indicator organisms for removal of pathogens by passage through saturated dune sand.Water Res. 2003;37(9):2186-94.DOI: 10.1016/So043-1354(02)00627-9 PMID: 12691904

26. Thomassen YE, van Eikenhorst G, van der Pol LA, Bakker WA. Isoelectric point determination of live polioviruses by capillary isoelectric focusing with whole column imaging detection. Anal Chem. 2013;85(12):6089-94.DOI: 10.1021/ac400968q PMID: 23672432

27. Simmons FJ, Kuo DH, Xagoraraki I. Removal of human enteric viruses by a full-scale membrane bioreactor during municipal wastewater processing.Water Res. 2011;45(9):2739-50.DOI: 10.1016/j.watres.2011.02.001 PMID: 21453953

28. Lodder WJ, Buisman AM, Rutjes SA, Heijne JC, Teunis PF, de Roda Husman AM. Feasibility of quantitative environmental surveillance in poliovirus eradication strategies.Appl Environ Microbiol. 2012;78(11):3800-5.DOI: 10.1128/AEM.07972-11 PMID: 22447593

29. Duintjer Tebbens RJ, Pallansch MA, Chumakov KM, Halsey NA, Hovi T, Minor PD, et al. Review and assessment of poliovirus immunity and transmission: synthesis of knowledge gaps and identification of research needs. Risk Anal. 2013;33(4):606-46. DOI: 10.1111/risa.12031 PMID: 23550968
30. Convention on the protection and use of transboundary watercourses and international lakes done at Helsinki, on 17 March 1992. Luxembourg: Official Journal of the European Communities; 1992. Available from: http://eur-lex.europa.eu/ legal-content/EN/TXT/PDF/?uri=CELEX:21995A0805(01)\&from $=\mathrm{EN}$

\section{License and copyright}

This is an open-access article distributed under the terms of the Creative Commons Attribution (CC BY 4.0) Licence. You may share and adapt the material, but must give appropriate credit to the source, provide a link to the licence, and indicate if changes were made.

This article is copyright of the authors, 2016. 